J. Japan. Assoc. Min.

Petr. Econ. Geol.

67, $311-322, \quad 1972$

\title{
METAMORPHIC HORNBLENDES FROM AN OUTCROP IN THE HITACHI DISTRICT
}

\author{
Hitoshi Onuki and Michio Tagiri
}

Institute of Mineralogy, Petrology and Economic Geology, Tohoku University, Sendai

\begin{abstract}
Six hornblendes and their host amphibolites collected from an outcrop in the Hitachi district were studied chemically. The metamorphic grade of the host rocks corresponds to the higher temperature part of the epidote amphibolite facies. There is no regular relation between the alkali contents in the hornblendes and their host rocks. With increasing $\mathrm{Ca} /(\mathrm{Ca}+\mathrm{Na})$ ratio of the host rock, this ratio of the hornblende remains nearly constant, although anorthite molecule in the coexisting plagioclase increases. Thus, the variation of $\mathrm{Ca} /(\mathrm{Ca}+\mathrm{Na})$ ratio of the host rock is mainly reflected on the composition of the plagioclase, but not on that of hornblende.
\end{abstract}

\section{INTRODUCTION}

The metamorphic terrains of the Abukuma plateau are divided into a main part which is called the central Abukuma plateau and the Hitachi district in the southernmost part. In the central Abukuma plateau, Miyashiro (1958) and Shido (1958) studied the metamorphic rocks in detail. Petrologic studies on the metamorphic rocks of the Hitachi district were carried out by Kuroda (1959) and Tagiri (1971). The metamorphic rocks of the Hitachi district are different from those of the central Abukuma plateau; that is, the assemblage sodic plagioclase $\left(<\mathrm{An}_{30}\right)$-epidote-common hornblende is well developed in the former (Kuroda, 1959; Tagiri, 1971), whereas this critical assemblage of the epidote amphibolite facies is practically lacking in the latter (Miyashiro, 1958; Shido, 1958). Based on the classification of mineral facies series in regional metamorphism proposed by Miyashiro (1971), the Hitachi metamorphism is regarded as interme- diate between the andalusite-sillimanite and kyanite-sillimanite types or as the low pressure intermediate group, while the central Abukuma metamorphism is characterized by the andalusite-sillimanite type or relatively high temperature and low pressure type (Tagiri, 1971).

Many investigators have discussed the relationship between the change of compositional range of calciferous amphiboles and the increasing grade of metamorphism. In this discussion the effect of bulk composition to the chemistry of hornblende should be taken into consideration. It is wellknown that calciferous amphibole is not hornblende, but tremolite-actinolite is produced by the amphibolite facies metamorphism in the rocks of appropriate composition, e.g. metamorphosed ultramafics and impure limestones.

In this paper the chemistry of the hornblendes and their respective amphibolites collected from an out crop in the Hitachi 
district is described, with some preliminary discussions on the dependence of the hornblende chemistry on the bulk composition.

The authors express their thanks to Professor Yoshio Ueda of the Tohoku University for his kind guidance. Sincere app- reciation is extend to Professor Kotora Hatai of the Tohoku University and Professor Kenzo Yagi of the Hokkaido University for their courtesy to read critically the manuscript with much improvement.

Table 1. Chemical compositions of metamorphic rocks

\begin{tabular}{|c|c|c|c|c|c|c|c|}
\hline & $\begin{array}{c}1 \\
\text { HT }-338\end{array}$ & $\begin{array}{c}2 \\
\mathrm{HT}-324\end{array}$ & $\begin{array}{c}3 \\
\mathrm{HT}-335\end{array}$ & $\begin{array}{c}4 \\
\mathrm{HT}-337\end{array}$ & $\begin{array}{c}5 \\
\mathrm{HT}-321\end{array}$ & $\begin{array}{c}6 \\
\text { HТO-13 }\end{array}$ & $\begin{array}{c}7 \\
\mathrm{HT}-341\end{array}$ \\
\hline $\mathrm{SiO}_{2}$ & 48.69 & 58.85 & 54.02 & 48.35 & 68.91 & 61.38 & 38.42 \\
\hline $\mathrm{TiO}_{2}$ & 0.81 & 0.37 & 1.09 & 0.38 & 0.58 & 0.73 & 1.20 \\
\hline $\mathrm{Al}_{2} \mathrm{O}_{3}$ & 13.72 & 13.31 & 15.75 & 16.03 & 13.01 & 15.48 & 21.75 \\
\hline $\mathrm{Fe}_{2} \mathrm{O}_{3}$ & 3.91 & 2.75 & 5.89 & 5.78 & 2.39 & 2.69 & 6.59 \\
\hline $\mathrm{FeO}$ & 6.28 & 6.74 & 6.20 & 10.26 & 4.19 & 4.69 & 11.52 \\
\hline $\mathrm{MnO}$ & 0.13 & 0.18 & 0.11 & 0.24 & 0.31 & 0.26 & 0.17 \\
\hline $\mathrm{MgO}$ & 10.78 & 6.56 & 3.89 & 6.25 & 2.01 & 2.09 & 8.04 \\
\hline $\mathrm{CaO}$ & 11.62 & 5.48 & 10.08 & 9.20 & 5.73 & 4.56 & 5.14 \\
\hline $\mathrm{Na}_{2} \mathrm{O}$ & 2.24 & 3.56 & 1.27 & 1.27 & 2.11 & 5.64 & 1.51 \\
\hline $\mathrm{K}_{2} \mathrm{O}$ & 0.24 & 0.15 & 0.13 & 0.17 & 0.18 & 0.64 & 0.19 \\
\hline $\mathrm{M}_{2} \mathrm{O}_{+}$ & 1.63 & 1.55 & 1.55 & 1.59 & 0.70 & 0.99 & 5.14 \\
\hline $\mathrm{H}_{2} \mathrm{O}-$ & 0.05 & 0.10 & 0.07 & 0.07 & 0.03 & 0.36 & 0.16 \\
\hline $\mathrm{P}_{2} \mathrm{O}_{5}$ & 0.08 & 0.11 & 0.15 & 0.09 & 0.13 & 0.19 & 0.12 \\
\hline Total & 100.18 & 99.71 & 100.20 & 99.68 & 100.28 & 99.70 & 99.95 \\
\hline I & 74.6 & 63.1 & 52.6 & 51.6 & 45.5 & 43.6 & 53.9 \\
\hline II & 66.2 & 55.7 & 37.6 & 41.7 & 35.8 & 34.0 & 43.8 \\
\hline III & 64.1 & 73.1 & 53.9 & 66.4 & 66.1 & 65,8 & 66.0 \\
\hline \multicolumn{8}{|c|}{ C.I.P.W. Norms } \\
\hline$q z$ & - & 13.32 & 19.49 & 6.81 & 39.07 & 12.55 & 0.31 \\
\hline or & 1.45 & 0.89 & 0.78 & 1.01 & 1.06 & 3.79 & 1.11 \\
\hline$a b$ & 18.93 & 30.11 & 10.75 & 10.74 & 17.85 & 47.73 & 12.79 \\
\hline an & 26.68 & 19.92 & 36.89 & 37.53 & 25.51 & 15.05 & 24.74 \\
\hline c & - & - & - & - & - & - & 10.00 \\
\hline \multirow{5}{*}{$\begin{array}{l}\text { py }\left\{\begin{array}{l}\text { wo } \\
\text { en } \\
\text { fs }\end{array}\right. \\
\text { ol }\left\{\begin{array}{l}\text { fo } \\
\mathrm{fa}\end{array}\right.\end{array}$} & 12.84 & 2.75 & 5.09 & 3.17 & 0.91 & 2.71 & - \\
\hline & 19.50 & 16.34 & 9.69 & 15.56 & 5.01 & 5.20 & 19.22 \\
\hline & 4.76 & 9.83 & 4.93 & 13.89 & 5.33 & 5.67 & 14.06 \\
\hline & 5.15 & - & - & - & - & - & - \\
\hline & 1.90 & - & - & - & - & - & - \\
\hline & 1.53 & 0.70 & 2.06 & 0.73 & 1.11 & 1.38 & 2.28 \\
\hline $\mathrm{mt}$ & 5.65 & 3.98 & 8.55 & 8.40 & 3.47 & 3.91 & 9.58 \\
\hline ap & 0.20 & 0.27 & 0.37 & 0.20 & 0.30 & 0.44 & 0.30 \\
\hline An \% & $22-24$ & $14-16$ & $27-30$ & $25-27$ & $20-22$ & $10-13$ & n.d. \\
\hline
\end{tabular}

I: $\mathrm{Mg} \times 100 /\left(\mathrm{Mg}+\mathrm{Fe}^{+2}+\mathrm{Mn}\right), \quad$ II $: \mathrm{Mg} \times 100 /\left(\mathrm{Mg}+\mathrm{Fe}^{+2}+\mathrm{Fe}^{+3}+\mathrm{Mn}\right), \quad$ III $: \quad \mathrm{Fe}^{+2} \times 100 /\left(\mathrm{Fe}^{+2}+\mathrm{Fe}^{+3}\right)$. Analyst: $H$. Onuki 


\section{Petrography and Petrochemistry}

All the samples used in this study were collected from a restricted portion (about 20 meters wide) of a quarry (50 meters wide and $5 \sim 15$ meters high) about 1.2 kilometers east of Machiya in the Hitachi district. This outcrop is quite heterogeneous and comprises amphibolites of various compositions derived from tuffs, tuffaceous sediments and lavas. The metamorphic grade of these rocks corresponds to the higher temperature part of the epidote amphibolite facies.

The mineral assemblages of the seven rocks studied are as follow:

Specimen No. HT-338; plagioclase-hornblende-cummingtonite-chlorite-epidote-sphene. Sp. No. HT-324; plagioclase-quartz-hornblende-cummingtonite-chlorite.

Sp. No. HT-335; plagioclase-quartz-hornblende-cummingtonite-epidote.

Sp. No. HT-337; plagioclase--hornblendecummingtonite-chlorite-sphene.

Sp. No. HT-321; quartz-plagioclase-hornblende-cummingtonite-chlorite-biotite.

Sp. No. HTO-13; quartz-plagioclase-hornblende-cummingtonite-chlorite-sphene.

Sp. No. HT-341; chlorite-cummingtoniteplagioclase-hornblende-sphene.

All of them include apatite and oxide minerals, mainly magnetite and rarely hematite. The magnetite-hematite association is found in two specimens (HT-324 and HT-321), but all the hematites may not be primary. The hornblende-cummingtonite association is always observed and is the most characteristic mineralogical feature of the rocks studied.

In the central Abukuma plateau cummingtonite does not occur in the lower temperature part but in the intermediate and higher temperature parts of the amphi- bolite facies. On the contrary, cummingtonite appears in the higher temperature part of the epidote amphibolite facies in the Hitachi district. Thus, this mineral is found in the Hitachi district at a temperature lower than in the central Abukuma plateau.

Hornblendes in all the samples are the blue-green variety (Miyashiro, 1958; Shido, 1958). Cummingtonite is found mostly in the marginal part of the hornblende crystals, and rarely as independent grains. The boundary between hornblende and cummingtonite is discrete, with Becke line. The exsolution lamellae of cummingtonite in hornblende and those of hornblende in cummingtonite are not microscopically observed.

The chemical compositions of the rocks studied are shown in Table 1, together with their C.I.P.W. norms and anorthite molecular per cent of their plagioclases infered from refractive indices $\alpha$ and $\gamma$. The chemical composition of a peculiar rock (HT-341), unusually rich in chlorite, is also

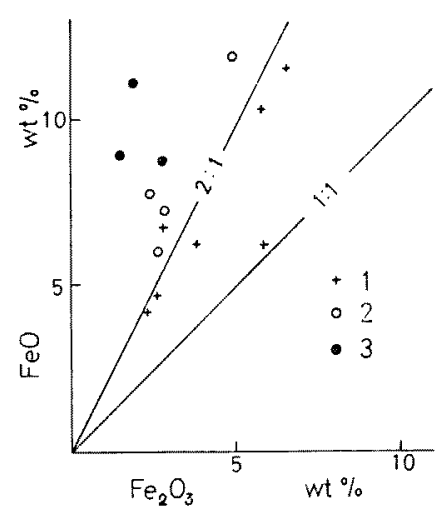

Figure 1. FeO and $\mathrm{Fe}_{2} \mathrm{O}_{3}$ contents of the basic metamorphic rocks from the Hitachi and central Abukuma districts.

The lines show $\mathrm{FeO} / \mathrm{Fe}_{2} \mathrm{O}_{3}=2: 1$ and $1: 1$ by weight.

1: The Hitachi metamorphic rocks (this study).

2: Rocks of the A zone of the central Abukuma district (Miyashiro, 1958).

3: Rocks of the $B$ zone of the central Abukuma district (Miyashiro, 1958). 
given in Table 1 for reference. These chemical compositions except HT-341 are arranged in the order of decreasing $\mathrm{Mg} \times 100 /$ $\left(\mathrm{Mg}+\mathrm{Fe}^{+2}+\mathrm{Mn}\right)$ ratio.

As clearly shown in Table 1, the bulk chemistry has a wide range from basic to acidic, but all the rocks, except HT-338, are oversaturated with silica in normative composition. These rocks are characterized generally by the high ferric/ferrous iron ratio. The analysed rocks of the epidote amphibolite facies of the Hitachi district

Table 2. Chemical compositions of hornblendes

\begin{tabular}{|c|c|c|c|c|c|c|}
\hline & $\begin{array}{c}1 \\
\mathrm{HT}-338 \mathrm{H}\end{array}$ & $\begin{array}{c}2 \\
\mathrm{HT}-324 \mathrm{H}\end{array}$ & $\begin{array}{c}3 \\
\mathrm{HT}-335 \mathrm{H}\end{array}$ & $\begin{array}{c}4 \\
\mathrm{H} T-337 \mathrm{H}\end{array}$ & $\begin{array}{c}5 \\
H T-321 H\end{array}$ & $\begin{array}{c}6 \\
\text { HTO-13 }\end{array}$ \\
\hline $\mathrm{SiO}_{2}$ & 47.14 & 48.41 & 42.98 & 43.79 & 43.94 & 45.11 \\
\hline $\mathrm{TiO}_{2}$ & 0.69 & 0.30 & 0.98 & 0.27 & 0.56 & 0.58 \\
\hline $\mathrm{Al}_{2} \mathrm{O}_{3}$ & 9.40 & 7.73 & 14.74 & 14.40 & 13.62 & 11.04 \\
\hline $\mathrm{Fe}_{2} \mathrm{O}_{3}$ & 4.86 & 3.11 & 5,03 & 4.74 & 6.76 & 5.68 \\
\hline $\mathrm{FeO}$ & 7.95 & 12.71 & 11.75 & 14.22 & 13.23 & 15.75 \\
\hline $\mathrm{MnO}$ & 0.24 & 0.31 & 0.12 & 0.27 & 0.41 & 0.40 \\
\hline $\mathrm{MgO}$ & 14.02 & 13.05 & 9.73 & 9.24 & 7.27 & 7.21 \\
\hline $\mathrm{CaO}$ & 12.31 & 11.15 & 11.11 & 11.09 & 10.91 & 10.30 \\
\hline $\mathrm{Na}_{2} \mathrm{O}$ & 1.17 & 1.19 & 1.39 & 1.20 & 1.40 & 1.28 \\
\hline $\mathrm{K}_{2} \mathrm{O}$ & 0.14 & 0.13 & 0.12 & 0.18 & 0.29 & 0.34 \\
\hline $\mathrm{H}_{2} \mathrm{O}+$ & 2.01 & 1.96 & 1.93 & 1.85 & 1.85 & 1.92 \\
\hline $\mathrm{H}_{2} \mathrm{O}-$ & 0.09 & 0.04 & 0.14 & $\operatorname{tr}$ & 0.04 & 0.19 \\
\hline Total & 100.08 & 100.09 & 99.97 & 100.25 & 100.28 & 99.80 \\
\hline \multicolumn{7}{|c|}{ Atomic ratios $(0=23)$} \\
\hline $\mathrm{Si}$ & 6.783 & 7.048 & 6.297 & 6.316 & 6.485 & 6.750 \\
\hline $\mathrm{Al}^{\mathrm{N}}$ & 1.217 & 0.952 & 1.703 & 1.684 & 1.515 & 1.250 \\
\hline$A]^{n-1}$ & 0.383 & 0.374 & 0.841 & 0.817 & 0.849 & $0 . \overline{693}$ \\
\hline $\mathrm{Ti}$ & 0.074 & 0.033 & 0.107 & 0.030 & 0.062 & 0.065 \\
\hline $\mathrm{Fe}^{+3}$ & 0.525 & 0.341 & 0.553 & 0.524 & 0.747 & 0.637 \\
\hline $\mathrm{Fe}^{+2}$ & 0.953 & 1.547 & 1.436 & 1.749 & 1.627 & 1.964 \\
\hline $\mathrm{Mn}$ & 0.029 & 0.038 & 0.015 & 0.034 & 0.051 & 0.050 \\
\hline $\mathrm{Mg}$ & 3.025 & 2.831 & 2.141 & 2.024 & 1.609 & 1.618 \\
\hline $\mathrm{Ca}$ & 1.897 & 1.738 & 1.746 & 1.753 & 1.725 & 1.651 \\
\hline $\mathrm{Na}$ & 0.326 & 0.336 & 0.394 & 0.344 & 0.400 & 0.370 \\
\hline $\mathrm{K}$ & 0.025 & 0.024 & 0.023 & 0.034 & 0.055 & 0.065 \\
\hline Total & 15.237 & 15.264 & 15.256 & 15.331 & 15.125 & 15.113 \\
\hline $\mathrm{H}_{2} \mathrm{O}$ & 0.964 & 0.952 & 0.943 & 0.910 & 0.910 & 0.957 \\
\hline I & 75.5 & 64.1 & 59.6 & 53.4 & 48.9 & 44.5 \\
\hline II & 66.7 & 59.5 & 51.6 & 47.0 & 39.9 & 34.2 \\
\hline III & 64.5 & 81.9 & 72.2 & 76.9 & 69.1 & 75.5 \\
\hline$\gamma$ & 1.662 & 1.666 & 1.678 & 1.685 & 1.685 & 1.688 \\
\hline $2 V x$ & $67 \sim 80^{\circ}$ & $64-80^{\circ}$ & $46 \sim 66^{\circ}$ & $60 \sim 66^{\circ}$ & $45-73^{\circ}$ & $60-67^{\circ}$ \\
\hline
\end{tabular}

I: $\mathrm{Mg} \times 100 /\left(\mathrm{Mg}+\mathrm{Fe}^{+2}+\mathrm{Mn}\right) . \quad$ II $: \mathrm{Mg} \times 100 /\left(\mathrm{Mg}+\mathrm{Fe}^{+2}+\mathrm{Fe}^{+3}+\mathrm{Mn}\right) . \quad$ III $: \mathrm{Fe}^{+2} \times 100 /\left(\mathrm{Fe}^{+2}+\mathrm{Fe}^{+3}\right)$. Analyst: $H$. Onuki 
have lower $\mathrm{FeO} / \mathrm{Fe}_{2} \mathrm{O}_{3}$ ratios than those in zone A (the greenschist facies) and in zone $B$ (the lower temperature part of the amphibolite facies) of the central Abukuma plateau. Namely, most of the metamorphic rocks treated in the Hitachi district fall in the field between the lines of $\mathrm{FeO} / \mathrm{Fe}_{2} \mathrm{O}_{3}=$ $2 / 1$ and $1 / 1$ by weight, while the metamorphic rocks in the central Abukuma plateau are plotted in the field where the $\mathrm{FeO} / \mathrm{Fe}_{2} \mathrm{O}_{3}$ ratio is higher than $2 / 1$ (Fig. 1). Thus, the metamorphic rocks in the Hitachi district and in the central Abukuma plateau have been formed under different oxygen partial pressures. This feature is important to interprete the different nature of the metamorphic rocks in these two districts.

\section{GHEMICAL COMPOSITION OF HORNBL- ENDES}

The chemical compositions of the hornblendes together with their atomic ratios on the anhydrous basis of $\mathrm{O}=23$ and physical data are listed in Table 2. Si has a range from 6.32 to 7.05 and $\mathrm{Al}^{\mathrm{IV}}$ varies from 0.90 to 1.70. The total of $\mathrm{Al}^{\mathrm{IV}}, \mathrm{Fe}^{+3}$ and $\mathrm{Ti}$ ranges from 0.75 to 1.66 and $\mathrm{Ca}$ from 1.65 to 1.90. The content of $(\mathrm{Na}+\mathrm{K})$ shows a narrow range from 0.33 to 0.46 .

According to the nomenclatures proposed by Deer et al. (1963), Miyashiro (1965) and Leake (1968), the analysed amphiboles are all "hornblendes". The most characteristic feature in the chemistry of these hornblendes is high content of $\mathrm{Fe}^{+3}$. Like their host rocks, the $\mathrm{Mg} \times 100 /\left(\mathrm{Mg}+\mathrm{Fe}^{+2}+\mathrm{Mn}\right)$ and $\mathrm{Mg} \times 100 /\left(\mathrm{Mg}+\mathrm{Fe}^{+2}+\mathrm{Fe}^{+3}+\mathrm{Mn}\right)$ ratios of the hornblendes have relatively wide ranges from 44.5 to 75.5 and from 34.2 to 66.7 , respectively.

Shido (1958) proposed a procedure for the calculation of these components the chemical composition of hornblendes by a number of theoritical end members. Onuki (1967) made a slight modification on Shido's method. Table 3 shows the results calculated by Onuki's method together with $\mathrm{Al}^{\mathrm{vi}} / \mathrm{Fe}^{+3}$ and also $\mathrm{Mg} / \mathrm{Fe}^{+2}$ ratios. These calculations are, however, useful only for

Table 3. Molecular proportions of hornblendes

\begin{tabular}{|c|c|c|c|c|c|c|}
\hline & $\begin{array}{c}1 \\
\mathrm{HT}-338 \mathrm{H}\end{array}$ & $\begin{array}{c}2 \\
\mathrm{HT}-324 \mathrm{H}\end{array}$ & $\begin{array}{c}3 \\
\mathrm{HT}-335 \mathrm{H}\end{array}$ & $\begin{array}{c}4 \\
\mathrm{HT}-337 \mathrm{H}\end{array}$ & $\begin{array}{c}5 \\
\mathrm{HT}-321 \mathrm{H}\end{array}$ & $\begin{array}{c}6 \\
\text { HTO-13H }\end{array}$ \\
\hline 'Tiam' & 148 & 66 & 214 & 60 & 124 & 130 \\
\hline Cum & - & 660 & 372 & 800 & - & 108 \\
\hline Ca-cum & 18 & - & - & - & 88 & - \\
\hline Ca-ed' & - & - & - & - & - & -- \\
\hline $\mathrm{Ed}^{\prime}$ & 238 & 264 & 256 & 331 & 125 & 113 \\
\hline Rieb & 456 & 384 & 644 & 188 & 1320 & 1288 \\
\hline Gl & - & - & - & - & - & - \\
\hline $\mathrm{Fe}^{+3} \mathrm{Ts}$ & 658 & 392 & 627 & 763 & 667 & 504 \\
\hline AlTs' & 640 & 602 & 1345 & 1306 & 1358 & 1106 \\
\hline $\operatorname{Tr}$ & 5842 & 5632 & 4542 & 4552 & 4318 & 4751 \\
\hline Total & 8000 & 8000 & 8000 & 8000 & 8000 & 8000 \\
\hline $\mathrm{Al}^{\mathrm{V}} / \mathrm{Fe}^{+3}$ & 0.73 & 1.10 & 1.52 & 1.56 & 1.14 & 1.09 \\
\hline $\mathrm{Na} / \mathrm{K}$ & 13.0 & 14.0 & 17.1 & 10.1 & 7.36 & 5.74 \\
\hline $\mathrm{Mg} / \mathrm{Fe}^{+2}$ & 3.17 & 1.83 & 1.49 & 1.16 & 0.99 & 0.82 \\
\hline
\end{tabular}


comparison of the gross chemical features of hornblende.

Judging from two equations noted below, Shido (1958) pointed out that hornblendes in silica-undersaturated rocks tend to have higher contents of alkalis than those in oversaturated rocks.

Tremolite Albite

$\mathrm{Ca}_{2} \mathrm{Mg}_{5} \mathrm{Si}_{8} \mathrm{O}_{22}(\mathrm{OH})_{2}+\mathrm{NaAlSi}_{3} \mathrm{O}_{8}$ Edenite Quartz

$=\mathrm{NaCa}_{2} \mathrm{Mg}_{5} \mathrm{Si}_{7} \mathrm{AlO}_{22}(\mathrm{OH})_{2}+4 \mathrm{SiO}_{2}$

Tremolite Albite

$\mathrm{Ca}_{2} \mathrm{Mg}_{5} \mathrm{Si}_{8} \mathrm{O}_{22}(\mathrm{OH})_{2}+2 \mathrm{NaAlSi}_{3} \mathrm{O}_{\mathrm{s}}$

Richterite Anorthite

$=\mathrm{Na}_{2} \mathrm{CaMg}_{5} \mathrm{Si}_{8} \mathrm{O}_{22}(\mathrm{OH})_{2}+\mathrm{CaAl}_{2} \mathrm{Si}_{2} \mathrm{O}_{8}$

Quartz

$+4 \mathrm{SiO}_{2}$

But the hornblendes under consideration do not clearly show such a tendency. Namely, the contents of alkalis in the hornblendes from quartz-free rocks (HT-338 and HT-341) are less than those in other hornblendes associated with quartz. For example, in the hormblende, HT-341H, which is found in the most basic rock, has very low alkali contents; i.e., $\mathrm{Na}_{2} \mathrm{O}$ and $\mathrm{K}_{2} \mathrm{O}$ are 1.25 and 0.18 weight per cent, respectively (complete analysis has not been carried out). Probably the abovementioned two reactions have progressed incompletely in the present district.

It is also noteworthy that $\mathrm{Ca}$ decreases from 1.90 to 1.65 with decreasing $\mathrm{Mg} /(\mathrm{Mg}+$ $\mathrm{Fe}^{+2}+\mathrm{Mn}$ ) ratio. As the causes for the decrease of $\mathrm{Ca}$ in hornblende, the cummingtonite $(\mathrm{NaAl} \leftrightarrows \mathrm{CaMg}), \quad$ glaucophane-riebeckite ( $\mathrm{NaAl}$ or $\mathrm{NaFe}^{+3} \rightleftarrows \mathrm{CaMg}$ ) and richterite $(\mathrm{Na} \rightleftarrows \mathrm{Ca})$ substitutions can be considered. Considering first cummingtonite substitution, we can not find clearly any correlation between $\mathrm{Ca}$ and $\left(\mathrm{Mg}+\mathrm{Fe}^{+2}+\mathrm{Mn}\right)$ or between $\mathrm{Ca}$ and $\mathrm{Mg} / \mathrm{Fe}^{+2}$ ratios. This substitution, therefore, is not so important for lowering $\mathrm{Ca}$ in these hornblendes. Next, alkalis are not well correlative to $\mathrm{Al}^{\mathrm{vi}}$, but tend to increase with increasing $\mathrm{Fe}^{+3}$ (Fig. 2). Thus, it may be pointed out that the

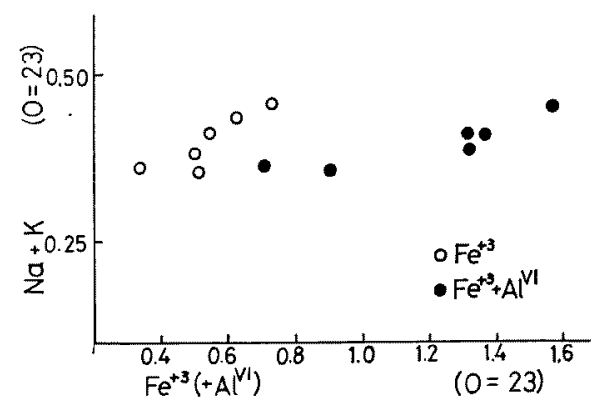

Figure 2. $(\mathrm{Na}+\mathrm{K})-\mathrm{Fe}^{+3}$ and $(\mathrm{Na}+\mathrm{K})-\left(\mathrm{Fe}^{+3}+\right.$ $\mathrm{Al}^{\mathrm{IV}}$ ) relations of hornblendes.

riebeckite substitution is more effective in these hornblendes. The estimation of the role of richterite substitution in hornblende is almost impossible at present. After the allotment of the atomic numbers calculated on anhydrous or hydrous basis to $(\mathrm{Z}),(\mathrm{Y}$, $X),(W)$ and (A) of hornblende structural sites, the role of the richterite substitution may be estimated on the basis of distribution of the alkalis and other atoms, though just expediently. Besides the following relation would be considered.

Richterite mol.

$2 \mathrm{Na}_{2} \mathrm{CaMg}_{5} \mathrm{Si}_{8} \mathrm{O}_{22}(\mathrm{OH})_{2}$

Tschermakite mol.

$+\mathrm{Ca}_{2} \mathrm{Mg}_{3}\left(\mathrm{AlFe}^{+3}\right)_{2} \mathrm{Si}_{6} \mathrm{Al}_{2} \mathrm{O}_{22}(\mathrm{OH})_{2}$

Edenite mol.

$=2 \mathrm{NaCa}_{2} \mathrm{Mg}_{5} \mathrm{Si}_{7} \mathrm{AlO}_{22}(\mathrm{OH})_{2}$

Glaucophane-riebeckite mol.

$+\mathrm{Na}_{2} \mathrm{Mg}_{3}\left(\mathrm{AlFe}^{+3}\right)_{2} \mathrm{Si}_{8} \mathrm{O}_{22}(\mathrm{OH})_{2}$

No reliable method for the estimation of the role of richterite substitution has been established.

Taken as a whole, the positive correlation between alkalis and $\mathrm{Fe}^{+3}$ in the hornblendes suggests a significant role of the 
riebeckite substitution in these hornblendes. This substitution should also have a great effect on the decrease of $\mathrm{Ca}$ in them.

The $\mathrm{Fe}^{+3} /\left(\mathrm{Fe}^{+2}+\mathrm{Fe}^{+3}\right)$ ratio in these hornblendes varies in a wide range of 0.18 to 0.35 just like in their host rocks, although the samples were collected from an extremely narrow area. This may suggest the irregular distribution of the oxygen partial pressure within the rocks and the low mobility of oxygen during metamorphism.

\section{Ghemical Compositions of Some Coexisting Minerals}

Hornblendes always coexist with cummingtonite in the rocks studied. Two analyses of cummingtonite and their atomic ratios on the anhydrous basis of $\mathrm{O}=23$ are given in Table 4. The two cummingtonites are lower in the $\mathrm{Mg} \times 100 /\left(\mathrm{Mg}+\mathrm{Fe}^{+2}+\mathrm{Fe}^{+3}\right.$
$+\mathrm{Mn}$ ) ratio and richer in $\mathrm{MnO}$ and $\mathrm{TiO}_{2}$ than those of the coexisting hornblendes.

It is generally noticed that cummingtonite occurs commonly in the metamorphic terrains characterized by relatively high temperature and low pressure metamorphism, but is usually absent in the terrains of relatively low temperature and high pressure metamorphism (Shido, 1958). If this is true, the prevailing occurrence of cummingtonite characterizes the Hitachi metamorphism.

Concerning the formation of cummingtonite, Shido (1958) suggested the following equation:

$$
\text { Tschermakite Quartz }
$$$$
7 \mathrm{Ca}_{2} \mathrm{Mg}_{3} \mathrm{Al}_{2} \mathrm{Si}_{6} \mathrm{Al}_{2} \mathrm{O}_{2 \mathrm{2}}(\mathrm{OH})_{2}+10 \mathrm{SiO}_{2}
$$$$
\text { Anorthite Cummingtonite }
$$$$
=14 \mathrm{CaAl}_{2} \mathrm{Si}_{2} \mathrm{O}_{8}+3 \mathrm{Mg}_{7} \mathrm{Si}_{8} \mathrm{O}_{22}(\mathrm{OH})_{2}
$$

Water

$+4 \mathrm{H}_{2} \mathrm{O}$

Table 4. Chemical analyses of cummingtonites

\begin{tabular}{|c|c|c|c|c|c|}
\hline \multicolumn{3}{|c|}{ Wt. \% } & \multicolumn{3}{|c|}{ Atomic ratios $(0=32)$} \\
\hline & $\begin{array}{c}1 \\
\mathrm{HT}-324 \mathrm{C}\end{array}$ & $\begin{array}{c}2 \\
\mathrm{HT}-337 \mathrm{C}\end{array}$ & & $\begin{array}{c}1 \\
\mathrm{HT}-324 \mathrm{C}\end{array}$ & $\begin{array}{c}2 \\
\text { HT }-337 \mathrm{C}\end{array}$ \\
\hline $\mathrm{SiO}_{2}$ & 52.02 & 49.80 & $\mathrm{Si}$ & 7.510 & 7.309 \\
\hline $\mathrm{TiO}_{2}$ & 0.41 & 0.33 & $\mathrm{Al}^{\mathrm{N}}$ & 0.490 & 0.691 \\
\hline $\mathrm{Al}_{2} \mathrm{O}_{3}$ & 3.67 & 4.15 & $\mathrm{Al}^{\mathrm{VI}}$ & 0.134 & 0.026 \\
\hline $\mathrm{Fe}_{2} \mathrm{O}_{3}$ & 4.38 & 5.97 & $\mathrm{Ti}$ & 0.044 & 0.036 \\
\hline $\mathrm{FeO}$ & 18.54 & 20.20 & $\mathrm{Fe}^{+3}$ & 0.474 & 0.657 \\
\hline $\mathrm{MnO}$ & 0.53 & 0.64 & $\mathrm{Fe}^{+2}$ & 2.236 & 2.471 \\
\hline $\mathrm{MgO}$ & 17.22 & 15.80 & $\mathrm{Mn}$ & 0.065 & 0.079 \\
\hline $\mathrm{CaO}$ & 1.68 & 1.28 & $\mathrm{Mg}$ & 3.729 & 3.558 \\
\hline $\mathrm{Na}_{2} \mathrm{O}$ & 0.12 & 0.12 & $\mathrm{Ca}$ & 0.260 & 0.202 \\
\hline $\mathrm{K}_{2} \mathrm{O}$ & 0.02 & 0.02 & $\mathrm{Na}$ & 0.033 & 0.033 \\
\hline $\mathrm{H}_{2} \mathrm{O}_{+}$ & 1.69 & 1.79 & $\mathrm{~K}$ & 0.003 & 0.004 \\
\hline $\mathrm{H}_{2} \mathrm{O}-$ & 0.01 & 0.04 & Total & 14.979 & 15.066 \\
\hline Total & 100.29 & 100.14 & $\mathrm{H}_{2} \mathrm{O}$ & 0.813 & 0.876 \\
\hline \multicolumn{4}{|c|}{$\mathrm{Mg} \times 100 /\left(\mathrm{Mg}+\mathrm{Fe}^{+2}+\mathrm{Mn}\right)$} & 61.8 & 57.7 \\
\hline \multicolumn{4}{|c|}{$\mathrm{Mg} \times 100 /\left(\mathrm{Mg}+\mathrm{Fe}^{+2}+\mathrm{Fe}^{+3}+\mathrm{Mn}\right)$} & 57.3 & 52.0 \\
\hline \multicolumn{4}{|c|}{$\mathrm{Fe}^{+2} \times 100 /\left(\mathrm{Fe}^{+2}+\mathrm{Fe}^{+3}\right)$} & 82.5 & 79.0 \\
\hline
\end{tabular}

1: Cummingtonite (HT-324). 2: Cummingtonite (HT-337). 
As the total volume of the solid phases on the left-hand side of the equation is smaller than that on the right-hand side, the occurrence of cummingtonite is favoured by lower rock pressures and higher temperatures. The analysed hornblendes from the metamorphic rocks belonging to the epidote amphibolite facies of the Hitachi district are more tschermakitic in composition than those from the metamorphic rocks corresponding to the lower temperature part of the amphibolite facies (zone B, Shido, 1958; Shido and Miyashiro, 1959) in the central Abukuma plateau. The appearance of cummingtonite may have started at lower temperature in the metamorphic rocks of the Hitachi district compared with those of the central Abukuma plateau. Probably above-noted reaction (1) is effective only in the central Abukuma plateau, but the cummingtonite in the Hitachi district should have formed in different way, possibly through the following equations:
Tremolite Amesite $\mathrm{Ca}_{2} \mathrm{Mg}_{5} \mathrm{Si}_{8} \mathrm{O}_{22}(\mathrm{OH})_{2}+2 \mathrm{Mg}_{2} \mathrm{Al}_{2} \mathrm{SiO}_{5}(\mathrm{OH})_{4}$ Antigorite Quartz $+4 \mathrm{Mg}_{3} \mathrm{Si}_{2} \mathrm{O}_{5}(\mathrm{OH})_{4}+10 \mathrm{SiO}_{2}$ Anorthite Cummingtonite Water $=2 \mathrm{CaAl}_{2} \mathrm{Si}_{2} \mathrm{O}_{8}+3 \mathrm{Mg}_{7} \mathrm{Si}_{8} \mathrm{O}_{22}(\mathrm{OH})_{2}+10 \mathrm{H}_{2} \mathrm{O}$ Epidote Amesite $6 \mathrm{Ca}_{2} \mathrm{Al}_{2} \mathrm{Si}_{3} \mathrm{O}_{12}(\mathrm{OH})+3 \mathrm{Mg}_{2} \mathrm{Al}_{2} \mathrm{SiO}_{5}(\mathrm{OH})_{4}$ Antigorite $+4 \mathrm{Mg}_{3} \mathrm{Si}_{2} \mathrm{O}_{5}(\mathrm{OH})_{4}$ Tschermakite Quartz $+\mathrm{Ca}_{2} \mathrm{Mg}_{3} \mathrm{Al}_{2} \mathrm{Si}_{6} \mathrm{Al}_{2} \mathrm{O}_{22}(\mathrm{OH})_{2}+17 \mathrm{SiO}_{2}$ Anorthite Cummingtonite Water $=14 \mathrm{CaAl}_{2} \mathrm{Si}_{2} \mathrm{O}_{8}+3 \mathrm{Mg}_{7} \mathrm{Si}_{8} \mathrm{O}_{22}(\mathrm{OH})_{2}+15 \mathrm{H}_{2} \mathrm{O}$ In both equations, the solid phases on the right-hand sides have slightly smaller total volumes than those of the left-hand sides. Thus, under higher rock pressures, these reactions go to the right, resulting in the formation of cummingtonite. Under the conditions of higher pressures and/or lower temperatures, these equations may be more effective than the equation (1). But these two reactions may be efficaceous only in

Table 5. Chemical analyses of chlorite and magnetite

\begin{tabular}{|c|c|c|c|c|c|}
\hline \multicolumn{3}{|c|}{ Wt. \% } & \multicolumn{3}{|c|}{$\begin{array}{c}\text { Atomic Ratios } \\
0=14\end{array}$} \\
\hline & $\begin{array}{c}1 \\
\mathrm{HT}-341 \mathrm{Ch}\end{array}$ & $\begin{array}{c}2 \\
\text { HT- } 341 \mathrm{M}\end{array}$ & & $\begin{array}{c}1 \\
\mathrm{HT}-341 \mathrm{Ch}\end{array}$ & $\begin{array}{c}2 \\
\mathrm{HT}-341 \mathrm{M}\end{array}$ \\
\hline $\mathrm{SiO}_{2}$ & 26.25 & 0.37 & $\mathrm{Si}$ & 2.636 & 0.114 \\
\hline $\mathrm{TiO}_{2}$ & 0.21 & 1.11 & $A l^{\mathrm{N}}$ & 1.364 & \\
\hline $\mathrm{Al}_{2} \mathrm{O}_{3}$ & 22.57 & 0.25 & $\mathrm{Al}^{\mathrm{n}}$ & 1.307 & 0.092 \\
\hline $\mathrm{Fe}_{2} \mathrm{O}_{3}$ & 3.47 & 67.35 & $\mathrm{Ti}$ & 0.016 & 0.256 \\
\hline $\mathrm{FeO}$ & 18.34 & 30.39 & $\mathrm{Fe}^{+3}$ & 0.262 & 15.547 \\
\hline $\mathrm{MnO}$ & 0.23 & 0.02 & $\mathrm{Fe}^{+2}$ & 1.540 & 7.795 \\
\hline $\mathrm{MgO}$ & 18.15 & tr. & $\mathrm{Mn}$ & 0.019 & 0.006 \\
\hline $\mathrm{CaO}$ & 0.10 & tr. & $\mathrm{Mg}$ & 2.715 & - \\
\hline $\mathrm{Na}_{2} \mathrm{O}$ & 0.12 & n.d. & $\mathrm{Ca}$ & 0.011 & - \\
\hline $\mathrm{K}_{2} \mathrm{O}$ & 0.02 & n.d. & $\mathrm{Na}$ & 0.023 & - \\
\hline $\mathrm{H}_{2} \mathrm{O}_{+}$ & 10.35 & 016 & $\mathrm{~K}$ & 0.002 & - \\
\hline $\mathrm{H}_{2} \mathrm{O}_{-}$ & 0.15 & 0.10 & Total & 9.895 & 23.810 \\
\hline Total & 99.94 & 99.65 & $\mathrm{H}_{2} \mathrm{O}$ & 3.465 & - \\
\hline
\end{tabular}

1: Chlorite (HT-341). 2: Magnetite (HT-341). 
restricted physical conditions of the same or nearly the same to the Hitachi metamorphism, because at much higher rock pressures the assemblage anorthite-cummingtonite will be replaced by the assemblage involving garnet as suggested by Shido (1958).

Chemical compositions of chlorite and magnetite from HT-341 are shown in Table 5. This chlorite is not oxidized and is termed orthochlorite. Since the $\left(\mathrm{Fe}^{+2}+\right.$ $\left.\mathrm{Fe}^{+3}\right) /\left(\mathrm{Mg}+\mathrm{Fe}^{+2}+\mathrm{Fe}^{+3}\right)$ ratio and $\mathrm{Si}$ atom calculated on the anhydrous basis of $\mathrm{O}=14$ are 0.38 and 5.3 , respectively, the mineral is defined as ripidolite (Deer et al., 1962). The ratio $\mathrm{TiO}_{2}: \mathrm{Fe}_{2} \mathrm{O}_{3}: \mathrm{FeO}$ in the magnetite is 1.12:68.13:30.75 in weight per cent and 1.64:49.12:49.26 in molecular per cent.

\section{The Relation Between Ghemical COMPOSITIONS ON HORNBLENDES AND THE Host RoGks}

Since hornblendes can contain almost all rock-forming elements as the components, their chemical composition is variable in a wide range, with extremely diverse isomorphous substitution. Since hornblendes, in nature, can be formed in metamorphic rocks of various compositions, it is not easy to analyse the relation in chemistry between the hornblendes and their host rocks. First the relatively minor components will be examined.

It is clear that $\mathrm{TiO}_{2}$ content in the hornblende is always lower than in the host rocks. So, these rocks must include one or more other minerals which are richer in $\mathrm{TiO}_{2}$ than coexisting hornblendes. As titaniumbearing minerals, sphene and magnetite are present in these rocks, but the $\mathrm{TiO}_{2}$ content of magnetite in this metamorphic grade may not exceed greatly that of the coexisting hornblende, judging from the composi- tion of magnetite in HT-341.

As shown in Fig. 3, the $\mathrm{TiO}_{2}$ contents in the hornblendes increase with increasing $\mathrm{TiO}_{2}$ contents of the host rocks, though always within the range less than 1 weight per cent $\mathrm{TiO}_{2}$ in the hornblendes. The maximum solubility of $\mathrm{TiO}_{2}$ in hornblende is determined by the temperature-pressure condition of metamorphism. The HT$335 \mathrm{H}$ shows the highest content of $\mathrm{TiO}_{2}$ ( 0.98 weight per cent) among the analysed hornblendes. Its host rock has an excess $\mathrm{TiO}_{2}$ represented by the presence of sphene. Probably the maximum content of $\mathrm{TiO}_{2}$ in hornblende is about 1 weight per cent under this metamorphic grade.

The $\mathrm{MnO}$ content of the hornblende is always higher than that of its host rock (Fig. 3).

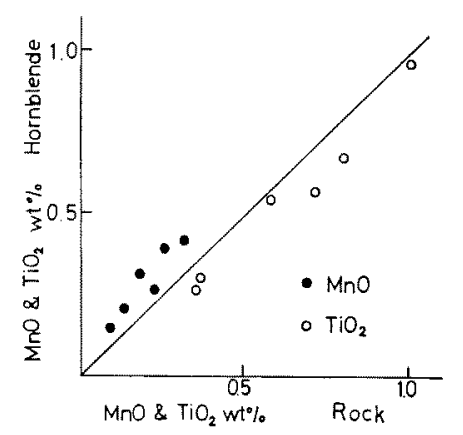

Figure 3. $\mathrm{MnO}$ and $\mathrm{TiO}_{2}$ contents of hornblendes and their host rocks.

Although the $\mathrm{K}_{2} \mathrm{O}$ contents are quite small in these hornblendes and also in their host rocks, the correlation of $\mathrm{K}_{2} \mathrm{O}$ between them appears to be positive in the available data. There is no regular relation between $\mathrm{Na}$ or $(\mathrm{Na}+\mathrm{K})$ contents in the hornblendes and those in their host rocks (Fig. 4). The maximum of the alkali contents in hornblendes can change depending on the rock chemistry only within the 
limits determined by the metamorphic condition.

The $\mathrm{Mg} \times 100 /\left(\mathrm{Mg}+\mathrm{Fe}^{+2}+\mathrm{Mn}\right)$ ratios in the hornblendes increase sympathetically

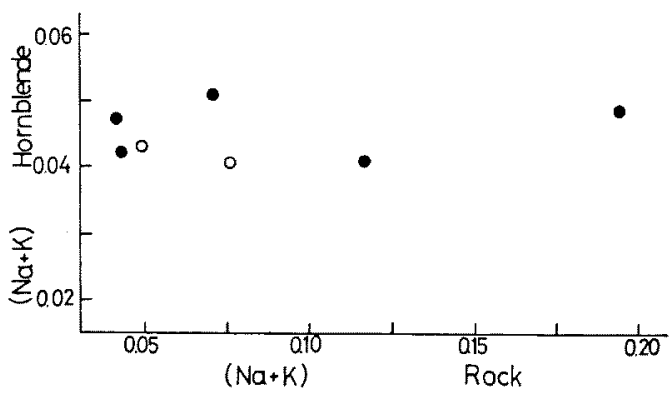

Figure 4. $(\mathrm{Na}+\mathrm{K})$ contents of hornblendes and their host rocks.

Open circles: Hornblendes not associated with quartz.

Closed circles: Hornblendes associated with quartz.

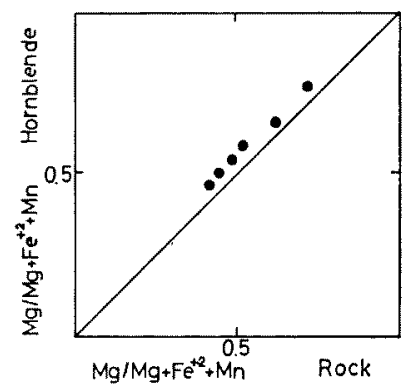

Figure 5. $\mathrm{Mg} /\left(\mathrm{Mg}+\mathrm{Fe}^{+2}+\mathrm{Mn}\right)$ ratios of hornblendes and their host rocks.

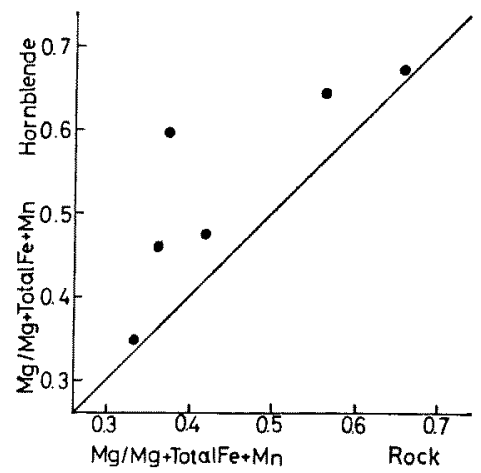

Figure 6. $\mathrm{Mg} /\left(\mathrm{Mg}+\mathrm{Fe}^{+2}+\mathrm{Fe}^{+3}+\mathrm{Mn}\right)$ ratios of hormblendes and their host rocks. to those of their host rocks (Fig. 5). The $\mathrm{Mg} \times 100 /\left(\mathrm{Mg}+\mathrm{Fe}^{+2}+\mathrm{Fe}^{+3}+\mathrm{Mn}\right)$ ratios of the hornblendes and their host rocks show also the same tendency except HT-335 (Fig. 6). Thus, the $\mathrm{Mg} \times 100 /\left(\mathrm{Mg}+\mathrm{Fe}^{+2}+\right.$ $\mathrm{Mn})$ and $\mathrm{Mg} \times 100 /\left(\mathrm{Mg}+\mathrm{Fe}^{+2}+\mathrm{Fe}^{+3}+\right.$ $\mathrm{Mn})$ ratios in the hornblendes appear to be almost entirely controlled by these ratios in the host rocks.

\section{Plagioclase-Hornblende Equili- BRIUM}

The relation between the compositions of plagioclase and hornblende is a key to clarify the relation between the bulk composition of the rocks and hornblende chemistry. Leake (1965), in his study on this relation, concluded that the $\mathrm{Ca} /(\mathrm{Ca}+\mathrm{Na})$ and $\mathrm{Al} / \mathrm{Si}$ ratios in both plagioclase and coexisting hornblende change systematically with increase in the grade of metamorphism, though the rock chemistry is also important. The rocks studied here were formed under nearly the same metamorphic grade and have plagioclases and hornblendes only as sodium-containing minerals. Therefore, the plagioclase-hornblende relation should be examined.

The $\mathrm{Ca} /(\mathrm{Ca}+\mathrm{Na})$ ratio of the hornblendes is nearly constant with a very narrow range from 0.79 to 0.84 , while this ratio of their host rocks varies from 0.29 to 0.80 , and that of plagioclases from 0.11 to 0.29 . With increasing $\mathrm{Ca} /(\mathrm{Ca}+\mathrm{Na})$ ratio of the host rock, therefore, anorthite molecule in the plagioclase increases but the ratio $\mathrm{Ca} /(\mathrm{Ca}+\mathrm{Na})$ of the coexisting hornblende remains nearly constant (Fig. 7). In other words, the $\mathrm{Ca} /(\mathrm{Ca}+\mathrm{Na})$ ratio of the hornblendes do not vary significantly with the change of this ratio in the host rocks, whereas the ratio of the associated plagioclases varies sensitively within the 


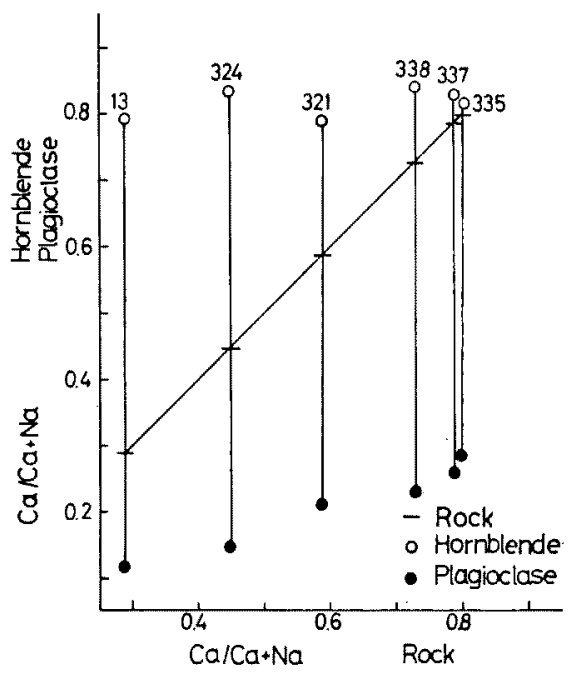

Figure 7. Relationship among $\mathrm{Ca} /(\mathrm{Ca}+\mathrm{Na})$ ratios of the hornblende, the coexisting plagioclase and the host rock.

HT- and HTO-prefixes have been omitted from the sample numbers.

limit determined by the physical conditions of metamorphism. The change of the anorthite content in plagioclase is accompanied by the change of the $\mathrm{Al} / \mathrm{Si}$ ratio of the mineral. There seem to be no systematic variation in the $\mathrm{Al} / \mathrm{Si}$ ratio among the homblendes, plagioclases and their host rocks.

The variation of $\mathrm{Ca} /(\mathrm{Ca}+\mathrm{Na})$ ratio of the host rocks is, therefore, mainly reflected on the changing composition of the plagioclases, but not that of hornblendes.

The maximum $\mathrm{Ca} /(\mathrm{Ca}+\mathrm{Na})$ ratio in both plagioclase and coexisting hornblende in metamorphic rocks would be determined by the metamorphic grade and may vary with increasing grade of metamorphism, but the variation of the ratio in each mineral may differ in different types of metamorphism. If this concept is true, the conclusion noted above may be not correct in all cases, but only in the higher temperature part of the epidote amphibolite facies in the Hitachi district. Further studies are needed to elucidate the nature of the equilibrium between these two minerals.

\section{REFERENGES}

Deer, W.A., Howie, R.A. and Zusmann, J. (1962), Rock-forming minerals, Vol. 3, Sheet silicates. Longmans, London, pp. 270.

- (1963), Rock-forming minerals, Vol. 2, Chain silicates, Longmans, London, pp. 379. Kuroda, Y. (1959), Petrological study on the metamorphic rocks of the Hitachi district, northeastern Japan. Sci. Rep. Tokyo Kyoiku Daigaku, Sec. 6, No. 58, 1-70.

Leake, B.E. (1965), The relationship between composition of calciferous amphibole and grade of metamorphism, 299-318. In Controls of metamorphism (W.S. Pitcher and G.W. Elinn, eds.), Jonh Wiley, New York, pp. 368.

(1968), A catalog of analysed calciferous and subcalciferous amphiboles together with their nomenclature and associated minerals. Geol. Soc. Am., Spec. 98, pp. 210.

Miyashiro, A. (1958), Regional metamorphism of the Gosaisho-Takanuki district in the central Abukuma plateau. Jour. Fac. Sci. Univ. Tokyo, Sec. 2, 11, 57-83.

(1961), Evolution of metamorphic belts. Jour. Petrol., 2, 277-311.

(1965), Metamorphic rocks and metamorphic belts. Iwanami, pp. 458 (in Japanese).

Onuki, H. (1967), Significance of molecular formulas in metamorphic hornblendes with relation to P-T conditions. Sci. Rep. Tohoku Univ., Ser. III, 10, 77-97.

Shido, F. (1958), Plutonic and metamorphic rocks of the Nakoso and Iritono districts in the central Abukuma plateau. Jour. Fac. Sci. Univ. Tokyo, Sec. 2, 11, 121-217.

- and, Miyashiro, A. (1959), Hornblendes of basic metamorphic rocks. Jour. Fac. Sci. Univ. Tokyo, Sec. 2, 11, 85-102.

Tagiri, M. (1971), Metamorphic rocks of the Hitachi district in the southern Abukuma plateau. Japan. Assoc. Min. Pet. Econ. Geol., 75, 77103. 


\section{日立地方，同一露頭からの变成ホルンブレンド}

$$
\text { 大貫仁・田切美智雄 }
$$

阿武幔山地，日立地方の同一露頭から 6 個の角閃岩類を選び，ホルンブレンドを分離し，化学分析を行なった。 との露頭は緑れん石角閃岩相の高温部に相当する。岩石の記载, ホルンブレンドの化学的性質などを述べたの 5, 岩石とホルンブレンドの間の化学的関倸を， $\mathrm{TiO}_{2}, \mathrm{MnO}$, アルカリ， $\mathrm{Mg} \times 100 /\left(\mathrm{Mg}+\mathrm{Fe}^{+2}+\mathrm{Mn}\right)$ などに ついて調べた。岩石中のアルカリ量の多少はホルンブレンドのアルカリ量に殆んど関倸がないてと，岩石の Ca/ $(\mathrm{Ca}+\mathrm{Na})$ 比が著しく変化してもホルンブレンドの同比は殆んど不変で, 共生する斜長石の $\mathrm{Ca} /(\mathrm{Ca}+\mathrm{Na})$ 比が 変化するにすぎないととなどが解った。な扔参考の為，ホルンブレンドと共存するカミングトン閃石 2 個，緑 泥石に著しく富んだ岩石ならびにての岩石中の緑泥石と磁鉄鉱の化学組成をも示した。 